\title{
エリスロポエチンの勃起機能に及ぼす影響
}

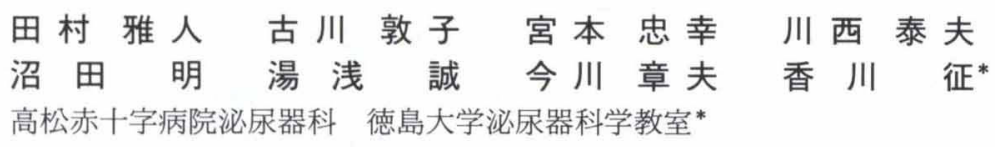

key words : hemodialysis patients, recombinant human erythropoietin, erectile function

〈要旨〉

慢性透析患者の貧血に対するエリスロポエチン (rEPO) の投与が広く行われ，すぐれた効果をあげている. rEPOの 投与による䨘血の改善に伴い勃起機能の改善が認められる症例が存在する. 今回は rEPO 投与前後の慢性透析患者の 勃起機能の評価を行った。 また, rEPO のヒト陰茎海綿体平滑筋に対する薬理学的な作用を検討した.

rEPO の投与を行った男性慢性透析患者 9 例のうち 4 例に䨘血の改善に伴う勃起機能の改善が見られた. また, $r E P O$ はヒト陰茎海綿体平滑筋に対し薬理学的な作用は認めなかった.

\section{Effect of erythropoietin on erectile function in hemodialysis patients}

Masato Tamura, Atsuko Furukawa, Tadayuki Miyamoto, Yasuo Kawanishi, Akira Numata, Makoto Yuasa, Akio Imagawa, Susumu Kagawa*

Department of Urology, Takamatsu Red Cross Hospital ; Department of Urology, School of Medicine, Tokushima University*

Recombinant human erythropoietin (rEPO) is the preferred treatment for anemia in chronic hemodialysis patients. The general status of hemodialysis patients improves, increasing their hematocrit value. Some patients have regained their erectile function after the use of $\mathrm{rEPO}$. We examined the erectile function of hemodialysis patients before and after treatment for anemia with $\mathrm{rEPO}$ and performed a pharmacological study of rEPO on isolated human corpus cavernosum tissue.

An improvement of erectile function was seen in four of 9 hemodialysis patients who were treated with rEPO. rEPO produced no pharmacological effects on isolated human corpus cavernousum tissue.

\section{緒言}

透析患者の貧血に対して遺伝子組み替えヒトエリスロ ポエチン（エリスロポエチン：rEPO）の投与が行われ, すぐれた貧血改善効果をあげて抢り, それに伴い生活面 での様々な自覚症状の改善が認められている. また, 透 析患者には種々の因子による勃起機能障害が認められる ことを我々はすでに報告しているる,. これらの勃起機能 障害が rEPO の投与による貧血の改善に伴い回復する 症例が存在する ${ }^{3)}$. 今回は慢性透析患者における $\mathrm{rEPO}$ 投与前後の勃起機能の評価と $\mathrm{rEPO}$ の上卜陰茎海綿体 平滑筋に対する薬理学的な作用を検討したので報告す る.

\section{対象および方法}

1. 臨床的検討

対象は $\mathrm{rEPO}$ の投与を施行した 32 歳から 62 歳 (平均 45.7 歳) の男性慢性透析患者 9 例である. 原疾患は糖尿 病性腎症 1 例, 慢性系球体腎炎 8 例で, 透析歴は 3 か月 から 9 年であった. $r E P O$ の投与は 1,500 単位を週 3 回 透析後に静脈内投与にて開始し, ヘマトクリット $(\mathrm{Ht})$ 值 $25 \%$ 以上を目標とした. 勃起機能の評価は rEPO 投与 前と貧血改善の目標値に達してから 1 か月以降に施行し た. 評価方法は visual analogue scale（図 1）による患 者自身の自覚症状の評価と erectometer（図 2)による nocturnal penile tumescence (NPT) の測定を行った.

田村 雅人 高松赤十字病院泌尿器科 $\quad$ T 760 高松市番町 4-1-3 (0878-31-7101)

〔受付：平成 3 年 1 月 8 日, 受理 : 平成 3 年 2 月 1 日) 
Visual analogue scale は水平の直線の左端に最も好ま しくない状態と右端に最も好ましい状態（健康であった 頃の状態とした）だけを示したものである. 勃起と性欲 に関して患者自身に現在の自分の状態を反映していると 考えられる位置に印を入れてもらい, 後で回収し線の位 置をスコアとして投与前後の評価を行った.

Erectometer は毛利ら ${ }^{4}$ の開発した日本人向けに改良 したものを用いた，就寝前に患者自身が陰茎に巻きつけ て印をつけ, 翌朝この目盛りのずれにより夜間陰茎勃起 を評価する方法である. REM 睡眠期の陰茎周径の増大 を確実にとらえる方法ではないが, 連続測定することに より信頼性の高い簡易法である. 測定は投与前後とも 3 夜連続施行し, 平均陰茎周径の増加により比較した。

2. 陰茎海綿体組織に対する薬理学的検討

実験材料は患者の同意のもとに陰茎手術時に得られた ヒト陰茎海綿体組織を $1 \times 2 \times 6 \mathrm{~mm}$ の切片とし, $37^{\circ} \mathrm{C} の$ Krebs 液を満たし $5 \%$ の $\mathrm{CO}_{2}$ を含む $\mathrm{O}_{2}$ で aerationし た $20 \mathrm{ml}$ の organ bath 内に $5 \mathrm{mN}$ の張力で懸垂し, 約 2 時間の equilibration の後に organ bath 内に薬剂を投 与し, 陰茎海綿体平滑筋の収縮弛緩を等尺性にトランス ジューサ (NEC sanei 45347A) にて記録した. Krebs 液

性欲について

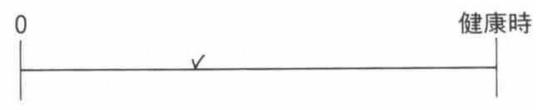

勃起の程度について

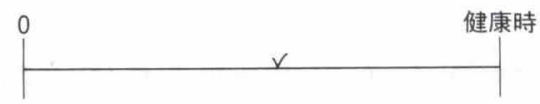

図 1 Visual analogue scale

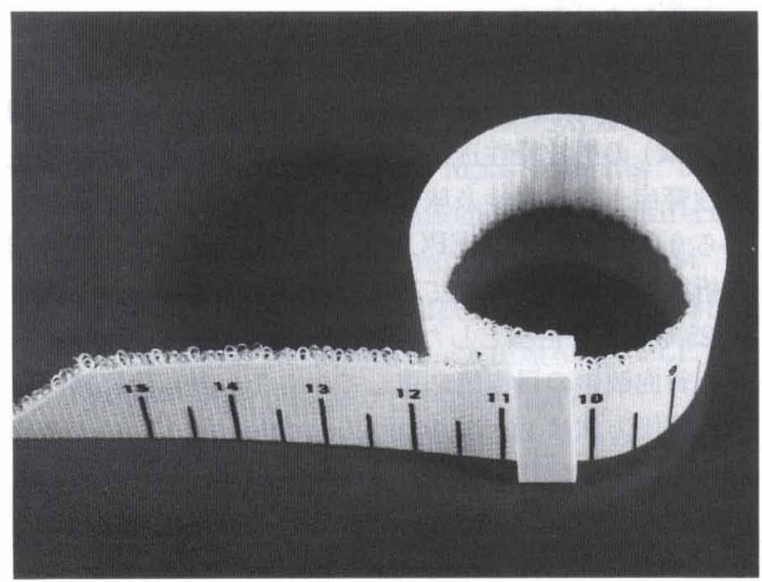

図 2 Erectometer
の組成は (単位は $\mathrm{mM}$ ) $\mathrm{NaCl} 119, \mathrm{KCl} 4.6, \mathrm{CaCl}_{2} 1.5$, $\mathrm{MgCl}_{2} 1.2, \mathrm{NaHCO}_{3} 15, \mathrm{NaH}_{2} \mathrm{PO}_{4} 1.2$, glucose 11 で $\mathrm{pH} 7.3 \sim 7.4$ に調整した. $124 \mathrm{mM}$ の高カリウム溶液に て $3 \mathrm{mN}$ 以下の収縮しか示さない切片は実験には用いな かった. Electrical field stimulation の刺激装置は日本 光電社製 SEN-3301 を用い, 刺激電極は長さ $5 \mathrm{~mm} の$ 白金線を $2 \mathrm{~mm}$ 離して海綿体の両側に置き, duration 0.8 $\mathrm{ms}, 15 \mathrm{~Hz}$ のパルス波で, 120 秒間隔で 5 秒間ずつ刺激し た. 刺激の強さは最大反応が得られる電圧で行い, その 収縮および弛緩に対する効果を検討した，透析患者に $\mathrm{rEPO} 1,500$ 単位を透析後に静脈内投与した場合の 4 時 間後までの血中濃度のピークは投与後数分で, $10^{2} \sim 10^{3}$ $\mathrm{mU} / \mathrm{m} l$ のオーダーであった（図 3 ). よって, 実験は organ bath 内の $\mathrm{rEPO}$ 濃度を $1,000 \mathrm{mU} / \mathrm{m} l, 2,000 \mathrm{mU} /$ $\mathrm{m} l$ とし, 陰茎海綿体平滑筋に対する作用を検討した.

結果

1. 臨床的検討

自覚症状の改善は性欲については 3 例に認めた。スコ アは投与前が $2.4 \pm 1.4$, 後が $2.7 \pm 1.8$ で全体として統 計学的な有意差は認めなかった. 勃起に関しては 5 例に 改善を認めた. スコアは投与前が $2.1 \pm 1.8$, 後か゚ $3.1 \pm$ 2.3 で, 全体として統計学的な有意差を認めなかった(図 4). 9 例の $\mathrm{Ht}$ の変化は投与前後で $19.3 \pm 3.5$ から $27.4 \pm 6.2$ となり, NPT の陰茥周径の増大の変化は $8.3 \pm 5.4$ から $12.4 \pm 7.3$ となった. $\mathrm{rEPO}$ の投与前後で 9 例中 6 例で陰茎周径の増大の増加を認めた(図 5 ).こ れら 6 症例中自覚症状においても改善を認めたのは 4 例 であった。

2. 陰茎海綿体組織に対する薬理学的検討

$\mathrm{rEPO}$ 自体の陰茎海綿体平滑筋に対する作用を図 6 に 示す. $1,000 \mathrm{mU} / \mathrm{m} l$ および $2,000 \mathrm{mU} / \mathrm{m} l$ の濃度では陰

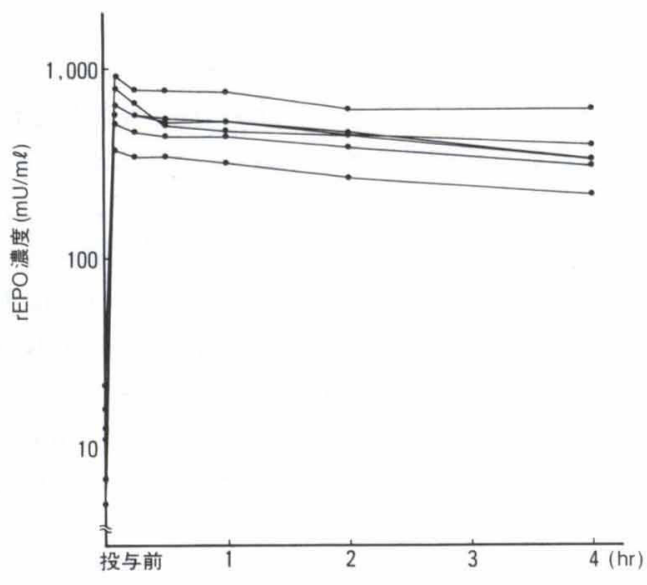

図 $3 \mathrm{rEPO}$ 投与時の血中濃度の推移（自験例） 

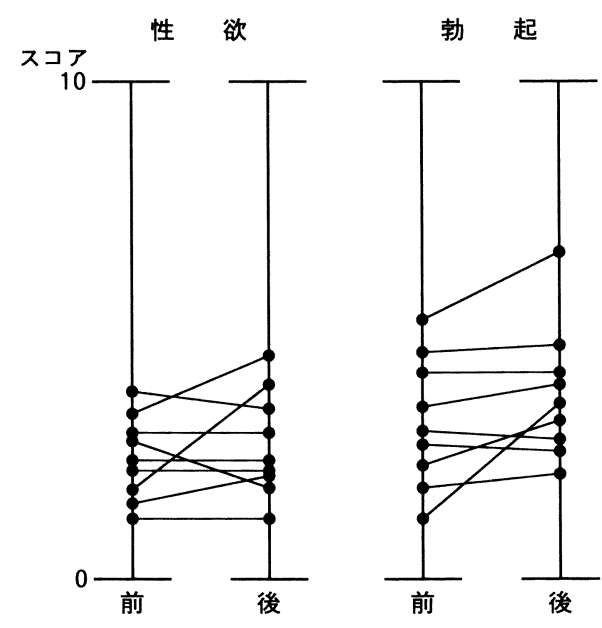

図 4 自覚症状の変化

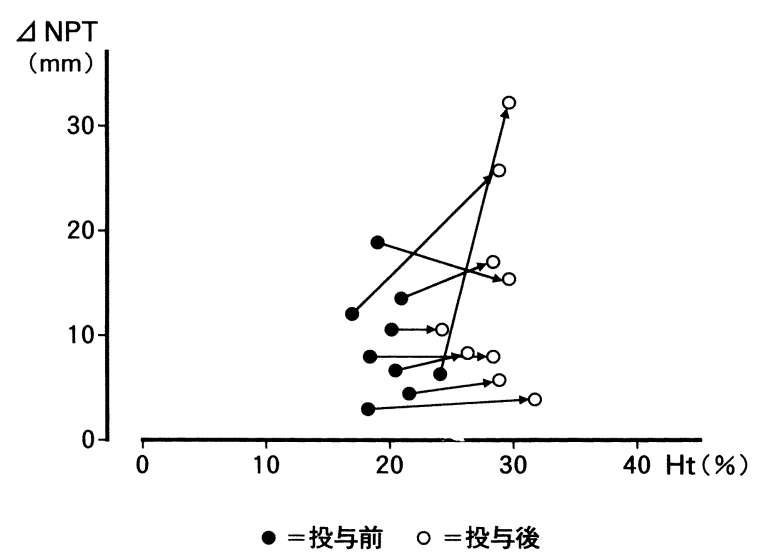

図 5 ヘマトクリット $(\mathrm{Ht})$ と NPT の変化

茎海綿体平滑筋組織に収縮および弛緩作用とも有しな

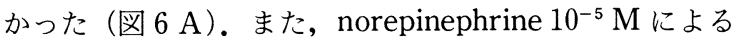
収縮に対して rEPO を投与したが，弛緩作用は認められ なかった(図 6 B). 続いて, electrical field stimulation に対する rEPO の効果を検討した．収縮反応に対する効 果, 弛緩に対する効果を示しているが，いずれも陰茎海 綿体平滑筋に対して rEPO は作用を示さなかった（図 6 C, D).

\section{考察}

透析療法の進歩に従い慢性透析患者の長期生存が可能 となり, 患者の quality of life (QOL) の問題が重視さ れるようになり，性機能に関する問題も論じられる機会 が増加してきた．勃起機能障害も性機能における大きな 問題の一つである. 慢性透析患者の勃起機能障害は性欲 の低下やホルモン環境の影響などの因子以外にも，神経 系および血管系など種々の因子によるものであることを
A
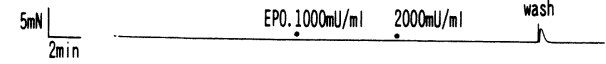

B

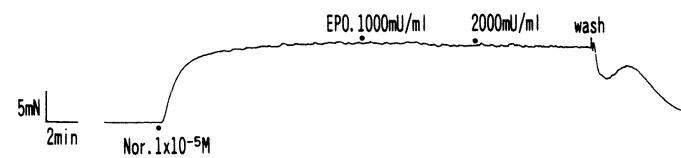

C

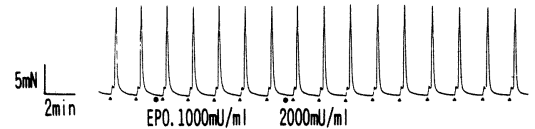

D

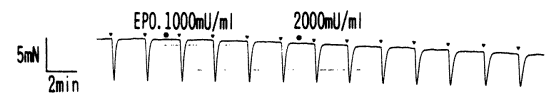

図 6 陰茎海綿体平滑筋に対する $\mathrm{rEPO}$ の作用

すでに報告している ${ }^{1,2)}$.

近年，慢性透析患者の貧血に対して rEPO の投与が行 われ，すぐれた貧血改善効果ともにさまざまな自覚症状 の改善が見られ QOL の向上が得られている。こうした 自覚症状改善の一つとして性機能の改善が見られること が諸家により報告されている ${ }^{5,6}$ が，これらは性機能全般 についてアンケート調査などによるもので，客観性に欠 けるものであり，勃起機能の改善に関しての客観性のあ る報告は少ない. 我々は, 今回 9 例の慢性透析患者の $\mathrm{rEPO}$ 投与前後の勃起機能を自覚所見と客観的に NPT の改善にて評価した. 自覚症状の改善は 9 例中 5 例に認 められた. NPT の改善は 9 例中 6 例に認めたが,このう ちの 3 例は $5 \mathrm{~mm}$ 以下の軽度の増加にとどまり, 自覚症 状の改善を伴ったのは 4 例のみであった.しかし, 神経 系および血管系の異常など種々の因子が存在する慢性透 析患者にこれだけの効果が得られたことは特筆すべきこ とであると考えられる。

こうした勃起機能の改善の機序を検討するために，今 回ヒト陰茎海綿体平滑筋に対する $\mathrm{rEPO}$ の急性の直接 作用を薬理学的に検討したところ, 陰茎海綿体平滑筋に は直接作用は有していなかった。つまり, rEPO の投与 による勃起機能の改善の機序として, rEPO 自体の陰茎 海綿体平滑筋への直接作用は影響しないことが確認され た. 勃起機能改善の機序として,まず第 1 に rEPO の投

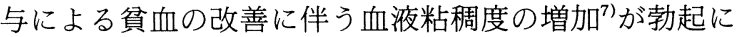
有利に働く可能性が考えられる ${ }^{3)}$.また, 貧血改善による 陰茎海綿体に対する慢性的な効果も考えられる. Schaefer $ら^{5,6)}$ は rEPO の投与により血清プロラクチン 值の有意な低下がみられ，性機能の回復が生じたと報告 しているが，これは推測するに中枢神経系でのドーパミ ン様作用が関与しているものと思われ，中枢における作 用が勃起機能の改善に関与している可能性も考えられ 
る. 今回の自験例では血清プロラクチンの有意な低下は 見られなかった，今後，症例を重祆ると共に機序と思わ れるこれらの因子について検討していきたい.

\section{文献}

1）川西泰夫, 今川章夫：透析患者の sexual potency と 下垂体・性腺機能。透析会誌 $17: 327-331 ， 1984$

2）川西泰夫, 今川章夫, 平石攻治, 黒川一男 : 透析患 者の勃起機能と精巣機能. 透析会誌 $20: 851-854$, 1987

3) Imagawa A, Kawanishi $Y$, Numata $A$ : Is erythropoietin effective for impotence in dialysis patients. Nephron $54: 95-96,1990$

4）毛利和富, 熊本悦明, 大野一典, 青木正治：新しい
インポテンスの鑑別診断法としての erectometer の有用性について. 日泌尿会誌 $76 ： 1478-1485,1985$

5) Schaefer RM, Kokot F, Wernze H, Geiger H, Heidland A : Improved sexual function in hemodialysis in recombinant erythropoietin : A possible role of prolactin. Clin Nephrol $31: 1-5$, 1989

6) Schaefer RM : Normalization of serum prolactin levels in hemodialysis patients on recombinant erythropoietin. Int J Artif Organs $12: 445-449$, 1989

7) Mayer G, Stefenelli Th, Cada EM, Thum J, Stummvoll HK, Graf H : Blood pressure and erythropoietin. Lancet ii : 351,1988 